\title{
Political Culture and the Crisis of Democracy. An Analysis of Citizenship Motivations to Justify a Coup D'état in Argentina*
}

\section{Cultura política y crisis de la democracia. Un análisis de las motivaciones de la ciudadanía para justificar un golpe de Estado en Argentina}

\author{
Daniela Alonso a \\ Universidad Nacional de Córdoba, Argentina \\ ORCID: https://orcid.org/0000-0003-2080-9571 \\ Silvina BRUSSINO \\ Universidad Nacional de Córdoba, Argentina \\ ORCID: https://orcid.org/0000-0002-1087-644X
} a Correspondence author. Email:
dalonso@unc.edu.ar

How to cite: Alonso, D., \& Brussino, S. (2021). Political culture and the crisis of democracy. An analysis of citizenship motivations to justify a coup d'état in Argentina. Universitas Psychologica, 20, 1-16. https://doi.org/10.11144/Javeriana.upsy20.pccd

\begin{abstract}
Latin American democracies are experiencing high instability, signed by economic and political crises and increasing social conflict. In this scenario, the continuity and further development of democracies are far from being granted. From a political psychology perspective, we are interested in understanding public motivations for justifying an authoritarian interruption of the democratic order. On a 454 Cordoba citizens sample (mean age $=37.3, \mathrm{SD}=14.22 ; 52.7 \%$ women, $47.3 \%$ men), we conducted a Discriminant Analysis to identify the more relevant dimensions for classifying people according to their attitudes towards a coup d'état. Six variables constituted the linear discriminant function resulting from a stepwise procedure $(\lambda=0.67$, $\chi^{2}=151.5, g l=6, p=0$ ) and enabled to classify $77.3 \%$ of the cases correctly. Conservative, normative, and ideological orientations were the more relevant dimensions to predict the justification of a state coup. Additionally, we identified two different attitudinal profiles among the people who are willing to justify a coup, mainly differentiated by their ideological orientations through a two-step cluster analysis. We accounted for a small group of people who justify a non-democratic exit to the socio-political conflict based on progressive ideological attitudes more than conservative or authoritarian orientations. Theoretical and practical implications of these findings are discussed.

Keywords

democracy; political legitimacy; political culture; authoritarianism; political ideology.

\section{RESUMEN}

Las democracias latinoamericanas experimentan una alta inestabilidad, signada por crisis económicas y políticas y una creciente conflictividad social. En este escenario, la continuidad y desarrollo de las democracias no parece estar garantizada. Desde una perspectiva psicopolítica, nos interesa comprender las motivaciones de la ciudadanía para justificar
\end{abstract}


una interrupción autoritaria del orden democrático. Para identificar las dimensiones de cultura política más relevantes para clasificar a las personas según sus actitudes frente a un golpe de Estado, condujimos un análisis discriminante sobre una muestra de 454 cordobeses/as (media de edad $=37.3, \mathrm{SD}=14.22 ; 52.7 \%$ mujeres, $47.3 \%$ hombres). Seis variables constituyeron la función lineal discriminante $\left(\lambda=0.67, \chi^{2}=151.5, g l=6, p=0\right) \mathrm{y}$ permitieron clasificar correctamente el $77.3 \%$ de los casos. Las orientaciones conservadoras, normativas e ideológicas fueron las dimensiones más relevantes para predecir la justificación de un golpe de Estado. Además, a través de un análisis de conglomerados en dos pasos, identificamos dos perfiles actitudinales entre quienes justificarían un golpe, diferenciados por sus orientaciones ideológicas. Así, identificamos un pequeño grupo de personas que parece justificar una salida no democrática al conflicto sociopolítico basado en actitudes ideológicas progresistas. Se discuten las implicaciones de estos hallazgos.

Palabras clave

democracia; legitimidad política; cultura política; autoritarismo; ideología política.

In a political scenario of social and political crisis, Latin American democracies' stability no longer seems guaranteed (Svampa, 2019; Zovatto, 2018). Circumstances such as the coup d'état in Bolivia, mass protests in Chile and Colombia, and the return of rightist parties to power in Brazil and Uruguay seem to endanger the continuity of democratic governments. Indeed, regional indexes such as Latinobarometer (Corporación Latinobarómetro, 2018) or Latin American Democratic Development Index (Índice de Desarrollo Democrático de América Latina [IDD-LAT], 2016) show a steady drop in explicit democracy support rates, alongside less political and social trust in a setting of high corruption, poverty, and inequality. Simultaneously, citizens massively claim for the fulfillment of frustrated expectations of a better quality of life and democratic institutionality: the consolidation of democracy has not been accompanied by improved system performance and institutional quality so that this democratic cycle seems to be reaching a peak of maximum tension (Levine \& Molina, 2007).

In this frame, our main objective is to empirically explore underlying citizens' motivations to justify the interruption of democracy. This is particularly relevant given that anticipating situations that might put democracies at risk have proved difficult. For example, the IDD-Lat pointed out that Chile and Uruguay were the countries with more democratic development during 2016. Only three years later, Chile is going through of extreme social conflict, while -for the first time in 15 years - a rightist conservative party has been elected in Uruguay. However, some data warns about the progressive loss of democracies' legitimacy, documenting an increasing gap between general democracy support and satisfaction with its performance, even in developed democracies (Dahlberg et al., 2015; Fuks et al., 2017). In Argentina, democracy explicit support has dropped from $70 \%$ in 2016 to $58 \%$ in 2018 , being the lowest since the 2001 economic and political crisis (Corporación Latinobarómetro, 2016, 2018). Nevertheless, satisfaction with democracy performance in the country issignificantly lower and has decreased from a $57 \%$ in 2016 to a $27 \%$ in 2018 . This posits a very problematic scenario for the future of this democracy.

From a theoretical point of view, a great deal of research on democracy legitimacy is based on political and sociological approaches addressing mainly the impact of institutional and economic performance on legitimacy attributions. Accordingly, legitimacy would be mainly based on endogenous features of institutional design, being favorable system outcomes a prerequisite for its consolidation (Mishler \& Rose, 2001; Murillo \& Visconti, 2017). However, this does not explain the survival of democracies of which performance is steadily under public expectations. On its part, a political culture perspective posits that system performance is not enough to explain more fundamental bonds of citizenry with democracy and that legitimacy stems mostly from socially transmitted cultural norms, exogenous to the political system itself (Mishler \& Rose, 2001).

The political culture perspective focuses on subjective elements of politics and analyzes the characteristics of a civic culture compatible with democratic values, assigning them a key role 
in the development and stability of democratic regimes (Marenco dos Santos, 2006). Framed in this perspective, a political psychology approach is pertinent for empirically explore underlying dimensions of citizens' bond with democracy. More specifically, we have studied the role of the prediction of the justification of a coup d'état of a set of political culture dimensions: normative, ideological, political sophistication, and socio-political context evaluation. These had previously demonstrated their correlation with more general attitudes towards democracy and could be relevant for understanding the current set back of democracy appreciation (Alonso, 2018; Alonso \& Brussino, 2018).

\section{Social Values, Ideology, and Democracy}

Social values embody group shared norms that guide actions, decisions, and social justifications and judgments (Pereira et al., 2005). From a psychosocial perspective, social values are political in nature since they do not merely express individual needs but reflect ideological affinities that orientate group interests (Barros et al., 2009; Caprara et al., 2017). In this regard, individual priorities are related to group membership and socio-economic and political conditions since people prioritize scarce things (Inglehart, 2000). This partially explains why macro-social analysis finds that materialist values (e.g., material security, hierarchy, authority) predominate in less developed democracies than WEIRD countries, where postmaterialist orientations (e.g., personal freedom, equality, expression) are widespread (Inglehart, 2007).

At the individual level, materialist values are linked to the adherence to rigid and absolutist normative systems and to more positive orientations towards authority, which also explains its relationship with religious values: they both provide rigid normative frameworks and tend to be associated with authoritarian and xenophobic political orientations (Inglehart, 2000; Pereira et al., 2005). On its part, those who prioritize postmaterialist values tend to show less need for certainty, better tolerate ambiguity, and endorse social and cultural change. These values prioritize freedom of speech, participation in government decisions, and political tolerance (Inglehart, 2000). Consequently, they are related to a fundamental commitment to democracy and its values, but they are usually accompanied by more criticism towards traditional political authorities and institutions (Barros et al., 2009; Pereira et al., 2001). On its part, hedonist values represent postmaterialist motivations associated with experimentation and openness to change; reflect individualist motivations; and are less compatible with political involvement and civic participation (Pereira et al., 2005).

A great deal of evidence coming from different sociopolitical scenarios documents that normative orientations are closely related to ideological orientations (e.g., Brussino et al., 2013, Dimdins et al., 2016; Solano Silva, 2018). For example, on a Brazilian student's sample, Barros et al. (2009) evidenced that materialist values were positively related to authoritarianism, while religious values were negatively related to political tolerance. In another study, Pereira et al. (2001) reported that religious values were related to negative attitudes towards democracy and postmaterialist values with positive orientations. On its part, Solano Silva (2018) reported a correspondence between conservative values and political ideology: those who ideologically placed themselves more to the right expressed less favorable attitudes towards income equality, greater resistance to change, and inequality acceptance.

These findings fit with conceptualizations of ideology that posit that the one-dimensional continuum left-right is inadequate to capture the complexity of ideological motivations (Dimdins et al., 2016). An alternative is to differentiate social and economic dimensions of ideology: while the first one opposes rejection vs. acceptance of social change, the latter refers to rejection vs. acceptance of inequality (Crawford et al., 2017). Based on this distinction, the system justification conceptualization of ideology postulates two different motivational bases for conservative orientations (dual-process model) (Kandler et al., 2016): the perception of the 
world as a ruthless jungle where competition over resources is unavoidable lies behind social dominance orientation (SDO). On its part, right-wing authoritarianism (RWA) reflects a perception of the world as threatening and dangerous, which leads to a search for security and a preference for social order.

Thus, SDO refers to the endorsement of a hierarchical and unequal social order where some groups exercise power over others, expressing economic conservatism. Meanwhile, RWA refers to the submission to legitimized authorities, aggressive response to norms violation, and endorsement of conventions and tradition, being more related to social conservatism (Altemeyer, 1996). Empirical evidence support this distinction: for example, Dimdins et al. (2016) found that RWA and SDO were both related to ideological conservatism, being RWA closer to social conservatism, and SDO to economic conservatism and system justification. However, both dimensions may predict more general attitudes towards the political system. For example, in Latin America, Rottenbacher and Schmitz (2012) evidenced that both RWA and SDO negatively predicted democracy support in Peru.

Finally, since it aims to explain how people rationalize and justify social injustices and inequality, we include the belief in a just world (BJW) in our analysis: BJW fulfills an adaptive purpose by reducing discomfort and uncertainty in the face of inequalities or unpredictable situations (Lipkus, 1991). It comprises the belief that the world is a fair place where everyone receives what they deserve and deserve what they receive. Consequently, it serves a system justification motive aligned with prevailing meritocratic worldviews. In this line, the literature found that BJW is positively related to variables such as religious values, SDO, RWA, and conservative political ideology (Jost et al., 2013). Thus, although there is not specific empirical evidence regarding BJW and its relationship with democratic attitudes, we expect this variable to follow the same pattern as other conservative orientations. Also, this conservative conglomerate may refer more to the justification of unequal or authoritarian regimes (in our case, a coup d'etat) than to justify the status quo itself (in our case, the preservation of democracy). Thus, system justification can support the current state of affairs and the search for social change towards idealized previous stages (Jost, 2019).

\section{Civic Competence, System Performance and Democracy}

Beyond the stated relevance of normative and ideological dimensions, an analysis of political culture from a psychosocial perspective regarding democracy support must also address the importance of the sociopolitical context. Hence, we include the role of civic competence and dimensions related to citizens' well-being in our analysis.

We analyze civic competence through the concept of political sophistication, including political knowledge and political interest (Oscarsson \& Rapeli, 2018). Welzel and Inglehart (2010) understand civic competence as a basic precondition for democracy: citizens must have basic tools to evaluate parties' performance, political alternatives, and understand electoral processes. Nevertheless, civic knowledge is insufficient as an analytical dimension: it is easy to access a vast deal of information in the current context. However, the comprehension and use made of it largely depend on other motivational aspects (Gibson \& McAllister, 2015). For this reason, in addition to evaluating civic knowledge, we include a motivational variable: political interest. In general terms, greater political sophistication is associated with stronger bonds with the political system and party institutions, greater political participation, and more progressive ideological orientations (Alonso, 2018; Muñiz et al., 2017). Thus, more politically sophisticated people may show a greater commitment to democracy.

Another prerequisite for the continuity of democracies lies in basic social and political trust, which reflects shared norms and values: democracy requires reciprocity norms that enable 
cooperation, empathy exercise, and tolerance (Santiago et al., 2020). As we stated before, Latin America lacks this kind of political and social integration, evidence of political alienation, which can, in turn, become a problem for democracy legitimacy (Grigera et al., 2016; Laca Arocena et al., 2011). In this regard, empirical evidence found positive correlations between social and political distrust, political cynicism, and social anomie, and that they discouraged social participation (Pattyn et al., 2012). Consequently, social anomie and political cynicism are analyzed together with social and political trust as symptoms of political alienation and social unrest.

Social anomie is the subjective correlate of social conditions of deregulation and the absence of clear norms (Teymoori et al., 2017). Thus, it implies the loss of meaning or reference, making it difficult to understand how the political system or the social world works, choose between different stimuli, and predict results. Literature suggests that in these scenarios normative, and social bases of democracy are weakened, corruption spreads, and people experiments threat (Benbenaste et al., 2008). Thus, anomie could result in authoritarian public reactions to regain control (Jugert \& Duckitt, 2009) and in a loss of social and political trust (Levina et al., 2016). In the same vein, political cynicism is defined as a generalized negative attitude towards politicians and politics, mainly based on the belief that politicians prioritize their personal interests over those of society (Pattyn et al., 2012). Thus, political cynicism entails widespread political distrust.

Altogether, these variables represent a subjective perspective of system performance: how the public perceives and evaluates the social and political context. In this frame, literature had documented that satisfaction with democracy functioning and government approval fluctuates alongside social and economic outcome evaluations (e.g., Corporación Latinobarómetro, 2018). Furthermore, this would be particularly true for newer or less developed democracies, where the link between the citizenry and the political system could be based to a greater extent on the situation than on an underdeveloped civic culture (Katz \& Levin, 2017; Mishler \& Rose, 2001). In this frame, it is possible that public endorsement of democracy drops when the system does not meet public expectations. However, some empirical evidence sustains that system performance is more relevant for shortterm government evaluation and approval but is less likely to erode basic commitment to democracy (for example, leading to extend support to a coup d'état) (Magalhães, 2016). Consequently, it is a relevant contribution to test the relative importance of normative-ideological orientations towards democracy compared to public perception of system performance on the basic commitment with the continuity of democracy.

\section{Method}

\section{Participants}

Four hundred and fifty-four citizens from Córdoba (AR) aged 18 to $70(\mathrm{M}=37.3$, $S D=14.2)$ responded to our questionnaire. Participants were selected through a nonprobabilistic sampling method depending on sex, age, and socioeconomic status (SES) quotas, which provided a sample with similar sociodemographic characteristics to the general population. According to the data provided by the permanent household survey of the National Institute of Statistics and Census (Muraro, 2012), these quotas were established. Women represented $52.6 \%$ of the sample, and men were $47.3 \%$ of the sample. Regarding socioeconomic status (SES), 26\% belonged to an upper-middle and upper SES, $31.6 \%$ to a middle SES, and the remaining 47.9 to a lower-middle and low SES.

\section{Measures}

Coup d'état justification. Five items assess how much a coup d'état is justified facing each scenario: social protest, high criminality rates, high unemployment rates, economic inflation, 
and political corruption (Vargas-Cullell et al., 2005). Response options range from $1=$ never justified to $10=$ totally justified. For classification purposes, we recoded the scores so that people who does not justify a coup d'état in any case (responded 1 to each item) is assigned to the "does not justify group" ( $\mathrm{N}=200)$ and people how does justify it in some or all of the scenarios (responded 2 or higher to any item) is assigned to the "justify group" $(\mathrm{N}=247)$.

Psychosocial Values. Inventory developed by Pereira et al. (2004). Comprises a list of 24 values addressing four normative systems: 1) materialistic values $(\alpha=0.80), 2)$ religious values $(\alpha=0.93), 3)$ hedonist values $(\alpha=$ $0.82)$, and 4) postmaterialist values $(\alpha=0.78)$. Response options range from $1=$ not important at all to $10=$ absolutely important, regarding their attributed relevance for the development of an ideal society.

Right-Wing Authoritarianism (RWA). Argentinean 6 item, brief version of the RWA scale (Etchezahar et al., 2011). Answered on a five-point Likert scale, it has a one-dimensional structure. A higher score indicates more RWA ( $\alpha$ $=0.81$ ).

Social Dominance Orientation (SDO). Argentinean adapted version (Etchezahar et al., 2014) of the SDO scale. It comprises ten items, answered on a five-point Likert scale and arranged on a bi-dimensional structure. Group Dominance Orientation: five items that assess participant's desirability of the existence of superior and inferior groups $(\alpha=0.71)$. Opposition to equality: five items that refer to the desirability of equality between people $(\alpha=$ 0.72 ). Regarding the latter, answers were reversed coded, so a higher score always indicates a higher SDO.

Global Belief in a Just World (GBJW). Locally adapted Spanish version of the GBJW scale originally developed by Lipkus (1991). This index consists of seven items answered in a six-point Likert scale format, and it has a one-dimensional structure $(\alpha=0.84)$.

Ideological Self-positioning. A single item requests the participant to place herself on a seven-point scale ranging from $1=$ totally left (more liberal) to $7=$ totally right (more conservative), being four the centrist position.

Political Tolerance. Americas Barometer Index (Latin American Public Opinion Project [LAPOP], 2014), which comprises four items assessing how willing people are to approve the public expression and participation (e.g., right to vote, right to run for public office) of people who openly "speak badly of the Argentinean government model." Response options range from $1=$ totally disapprove to $10=$ totally approve. A higher score shows a higher level of tolerance.

Political Trust. We measured trust levels in judicial, legislative, and executive branches. Participants had to indicate the level of honesty and good performance they attributed to each one on a five-point scale, from $1=$ almost nothing to $5=$ a lot. These two dimensions honesty and performance- have been identified as core elements of trust in previous research (Segovia et al., 2008). We combine the answers on a one-dimension index of political trust $(\alpha=$ 0.83).

Social Trust. Two items that assess the general level of interpersonal trust based on the VargasCullell et al. (2005) social trust index also answered a five-point Likert scale.

Anomie Perception. Spanish version of the anomie scale (Rodríguez García, 2006) comprises nine items answered on a five-point Likert scale. This index shows a one-dimensional structure and an optimal reliability level $(\alpha=0.79)$.

Political Cynicism. A locally adapted scale (Brussino et al., 2015) consisting of five items that assess cynical attitudes toward politicians and how they exercise their role. It is answered on a six-point Likert Scale and has a onedimensional structure $(\alpha=0.87)$.

Political Knowledge. Political and civic knowledge scale locally validated by Brussino et al. (2008). It comprises eight open questions coded as follows: $0=$ don't know/incorrect, $1=$ partially correct, and $2=$ correct. The sum of correct and partially correct answers results in the total scale score $(\alpha=0.73)$.

Political Interest. Locally adapted and tested index (Brussino et al., 2009). Comprises six items on a one-dimensional structure $(\alpha=0.93)$ that 
pose different politics-related situations to which the person must respond, indicating the level of interest that they generate on a scale that ranges from $1=$ no interest at all, to $5=$ a lot of interest.

Vote. We asked the participants for whom they had voted in the second round of the 2015 presidential elections. Answers were classified according to whether it was a vote for Mauricio Macri (winner vote, $\mathrm{N}=215$ ) or Daniel Scioli (loser vote, $\mathrm{N}=145$ ). Those who did not vote or did so in blank were lost cases in this variable.

Democratic Legitimation. Considering the Latinobarometer's index and the World Values Survey items, we developed our democracy preference index. It has four items answered on a six-point Likert scale $(\alpha=0.71)$, which assess the preference for democracy together with the rejection of authoritarian ways of government. Items were coded so that a higher score always indicates a more positive orientation toward democracy.

Argentinean Political System Justification (APSJ). A Spanish version of the Rutto et al. (2014) Democratic System Justification index was used. This measure assesses system support at a local level, asking specifically about attitudes towards the Argentine Political System. So, it measures a specific dimension of system legitimation; APSJ comprises eight items answered on a five-point Likert scale coded so that a higher score indicates higher levels of system justification $(\alpha=0.71)$.

Socio-demographic variables. Sex, age, and educational level were controlled through closeended questions.

\section{Procedure}

Data were collected through a closed questionnaire containing the described data collection instruments. Participants were recruited in public places, and both members of the research team and trained students conducted face-to-face interviews. Before answering the questionnaire, each participant was explained the study's goals and asked for their explicit consent. We also established that participation was voluntary and their answers anonymous, confidential, and would only be used for research purposes.

\section{Data analysis}

Data were processed using SPSS19. First, we conducted descriptive analysis and identified multivariate outliers by estimating Mahalanobis distance, which resulted in eliminating of eight atypical cases. Next, we estimated the psychometric properties of our variables, asymmetry and kurtosis indexes, correlations between all the variables, and homogeneity of variances. We also conducted mean differences analysis to detect differences between groups in each variable and decided whether it was necessary to eliminate some of them from the subsequent Discriminant Analysis (DA). Once we checked all the pertinent prerequisites, we proceeded to the linear DA. This analysis enables to test to which extent sociodemographic, normative, ideological, political sophistication, and socio-political context evaluation variables are relevant to classify people according to their attitudes towards a coup d'état. We used a stepwise method to select only the variables with the highest Wilk's lambda up to the point that performance of cross-validated prediction of group membership no longer improved. Also, we estimated the percentage of cases correctly assigned and cross-validated this assignation through the leave-one-out method. Finally, to reach a better understanding of the attitudinal characterization of people who somehow justify a state coup, we explored the composition of that group conducting a two-step cluster analysis. This technique allows us to form groups according to their similarity in a set of variables. We considered only the participants in the "justifies coup d'état group" ( $\mathrm{N}=200)$ and included in the analysis the same variables as the DA. However, we added general (democracy legitimacy) and specific (Argentinean political system justification) political support variables and voter choice (winner vs. loser). Contrary to $\mathrm{DA}$, this technique allows categorical variables 
to be included and does not require any previous categorization of participants.

\section{Results}

As we noted above, 200 participants were included in the "does not justify a coup d'état group" (group 1), and the remaining 247 were included in the "justify a coup d'etat group" (group 2). The level of justification of a coup d'état was relatively low since only $35 \%$ of the people on group 2 scored above the media of the scale. Also, 66 cases had to be excluded since they did not position themselves on the ideology scale (they were missing cases for this variable). Consequently, group 1 was formed by 181 participants and group 2 by 200 participants.

Table 1 describes the two groups regarding the variables under study and presents a mean difference analysis.

\section{Table 1}

Mean differences analysis between group 1 (does not justify a coup d'état) and group 2 (justify a coup d'état)

\begin{tabular}{|c|c|c|c|c|c|}
\hline \multirow{2}{*}{ Variables } & \multicolumn{2}{|c|}{ Group 1} & \multicolumn{2}{|c|}{ Group 2} & \multirow{2}{*}{$t$} \\
\hline & $M$ & $S D$ & $M$ & $S D$ & \\
\hline \multicolumn{6}{|l|}{ Sociodemographic Variables } \\
\hline Age & 38.56 & 14.63 & 35.37 & 13.62 & $2.21^{*}$ \\
\hline SES & 4.02 & 1.12 & 3.50 & 1.07 & $4.68^{* * *}$ \\
\hline Educational Level & 5.89 & 1.10 & 5.27 & 1.16 & $5.39^{* * *}$ \\
\hline \multicolumn{6}{|l|}{ Normative Variables } \\
\hline Materialistic Values & 18.39 & 7.79 & 23.35 & 7.54 & $6.31^{* * *}$ \\
\hline Religious Values & 12.33 & 10.36 & 18.13 & 12.31 & $4.96^{* * *}$ \\
\hline Hedonist Values & 24.14 & 8.43 & 25.80 & 7.81 & $2^{*}$ \\
\hline Posmaterialist Values & 78.79 & 9.09 & 76.86 & 9.56 & $2.01^{*}$ \\
\hline \multicolumn{6}{|l|}{ Ideological Variables } \\
\hline RWA & 12.58 & 6.42 & 19.15 & 6.20 & $10.15^{* * *}$ \\
\hline SDO - Group Dominance & 8 & 3.43 & 10.99 & 3.98 & $7.80^{* * *}$ \\
\hline SDO - Opposition to Equality & 7.33 & 3.08 & 8.39 & 3.19 & $3.30^{* * *}$ \\
\hline GBJW & 15.12 & 6.42 & 19.95 & 7.26 & $6.86^{* * *}$ \\
\hline Ideological Self-position & 3.12 & 1.2 & 4.04 & 1.21 & $7,41^{* * *}$ \\
\hline Political Tolerance & 32.5 & 9.22 & 26.71 & 9.53 & $6.02^{* * *}$ \\
\hline \multicolumn{6}{|l|}{ Political Sophistication } \\
\hline Political Knowledge & 8.87 & 3.40 & 7.06 & 3.64 & $4.98^{* * *}$ \\
\hline Political Interest & 21.54 & 6.7 & 16.89 & 7.01 & $6.60^{* * *}$ \\
\hline \multicolumn{6}{|l|}{ Socio-Political Context Evaluation } \\
\hline Political Trust & 12.99 & 4.71 & 14.09 & 4.5 & $2.33^{*}$ \\
\hline Social Trust & 4.84 & 1.91 & 3.82 & 1.76 & $5.39^{* * *}$ \\
\hline Anomie Perception & 24.98 & 6.99 & 29.99 & 7.11 & $6.93^{* * *}$ \\
\hline Political Cynicism & 15.94 & 4.95 & 17.91 & 4.39 & $4.11^{* * * *}$ \\
\hline
\end{tabular}

All variables presented statistically significant differences between groups conformed by people's attitudes toward a coup d'état. Consequently, we decided to include all the analytical dimensions to perform the DA. The differences followed the expected pattern matching the previous evidence, except for political trust, which we will discuss later.

The Box $M$ test results did not reflect significant differences between the covariance matrices of the two groups $(\mathrm{M}=24.50 ; \mathrm{F}$ $=1.15 ; p=0.29$ ). Therefore, there is a solid criterion for the application of DA. Six variables constituted the linear discriminant function when a stepwise procedure was applied: Age, SES, post-materialism, GBJW, RWA, and Ideological Self-positioning. Wilk's lambda resulted statistically significant $\left(\lambda=0.67, X^{2}\right.$ $=151.5, g l=6, p=0)$ and canonical correlation coefficient adequate $(r=0.58)$, which suggests that the linear function is suitable for differentiating the groups. Based on the centroid's values, it can also be stated that the groups are properly separated (Table 2 ).

\section{Table 2}

Functions in the centroids of the groups

\begin{tabular}{lr}
\hline \multicolumn{1}{c}{ Groups } & Function 1 \\
\hline 1) Does not Justify a Coup d'état & -0.739 \\
2) Justify a Coup D'état & 0.668 \\
\hline
\end{tabular}

To assess the relative relevance of each variable in the model, we present the standardized coefficients of the canonical discriminant function (Table 3). 
Table 3

Standardized coefficients of the canonical discriminant function

\begin{tabular}{lr}
\hline \multicolumn{1}{c}{ Standarized coefficient } & Function 1 \\
\hline RWA & 0.641 \\
Age & -0.527 \\
GBJW & 0.347 \\
Ideological Self-positioning & 0.293 \\
SES & -0.232 \\
Postmaterialist Values & -0.196 \\
\hline
\end{tabular}

None of the variables related to the specific sociopolitical scenario were relevant to discriminate between the two groups, being ideological dimensions the most critical to predicting attitudes towards a coup: people who hold more conservative ideological orientations is more likely to support a state coup. Also, younger people and lower SES people justified more a coup d'état.

Finally, $77.3 \%$ of cases were correctly classified after cross-validation (Table 4), which is much higher than the maximum randomness criterion $(52.5 \%)$ and meets the criteria of classification accuracy that requires a quarter above the percentage obtained by randomness.

Table 4

Correctly Classified Percentage of participants

\begin{tabular}{|c|c|c|c|c|c|}
\hline \multirow{2}{*}{ Classificatior } & & \multirow{2}{*}{$\begin{array}{l}\text { Attitudes towards } \\
\text { a Coup d'état }\end{array}$} & \multicolumn{2}{|c|}{ Predicted Group } & \multirow{2}{*}{ Total } \\
\hline & & & Does Not Justify & Justify & \\
\hline \multirow[t]{4}{*}{ Original } & Count & Does Not Justify & 142 & 39 & 181 \\
\hline & & Justify & 44 & 156 & 200 \\
\hline & $\%$ & Does Not Justify & 78.5 & 21.5 & 100 \\
\hline & & Justify & 22 & 78 & 100 \\
\hline Cross & Count & Does Not Justify & 140 & 41 & 181 \\
\hline \multirow[t]{3}{*}{ Validation } & & Justify & 44 & 156 & 200 \\
\hline & $\%$ & Does Not Justify & 77.3 & 22.7 & 100 \\
\hline & & Justify & 22 & 78 & 100 \\
\hline
\end{tabular}

Note. $78.2 \%$ of original cases correctly classified and $73.3 \%$ of cases correctly classified after cross-validation.

Altogether, this suggests that the sociopolitical scenario is less relevant compared to ideological orientations when it comes to the justification of democratic order disruption. Also, since we are interested in deepening our understanding of the motivations underlying the justification of a coup d'état, we conducted a two-step cluster analysis including only the participants who expressed -to some extendwillingness to justify a coup $(\mathrm{N}=200)$.

We found a two-cluster solution based on 165 respondents (since 35 could not be classified) with a silhouette measure of cohesion and separation of 0.2. Three ideological variables were especially relevant to predict the cluster membership: vote, ideological self-positioning, and RWA. Cluster 1 is much bigger $(\mathrm{N}=127)$, characterized by more conservative ideological orientations, higher levels of authoritarianism, and having voted for Mauricio Macri (a centerright candidate). Cluster 2 is much smaller ( $\mathrm{N}$ $=38$ ) and expresses the opposite ideological orientations. Thus, almost a quarter of the people willing to justify a coup seemed to base their attitudes on progressive motivations rather than on the motivations to sustain and justify the status quo. Table 5 shows differences between the clusters, ordered according to their relevance on the model. 
Table 5

Relevance of predictor, mean, standard deviation and test between cluster $1(\mathrm{~N}=127)$ and cluster $2(N=38)$

\begin{tabular}{|c|c|c|c|c|c|c|}
\hline \multirow[t]{2}{*}{ Variables } & \multirow[b]{2}{*}{ Relevance } & \multicolumn{2}{|c|}{ Cluster 1} & \multicolumn{2}{|c|}{ Cluster 2} & \multirow[b]{2}{*}{$t$} \\
\hline & & $M$ & $S D$ & $M$ & $S D$ & \\
\hline \multicolumn{7}{|l|}{ Vote } \\
\hline Mauricio Macri & & & $92.9 \%$ & & $0 \%$ & ${ }^{a} V=0.8$ \\
\hline Daniel Scioli & 1 & & $7.1 \%$ & & $100 \%$ & $7^{* * *}$ \\
\hline Ideological Self-positioning & 0.6 & 4.46 & 0.92 & 2.82 & 0.95 & $9.58^{* * *}$ \\
\hline RWA & 0.25 & 21.13 & 5.19 & 13.18 & 4.42 & $8.55^{* * *}$ \\
\hline Political Cynicism & 0.2 & 18.54 & 3.79 & 14.34 & 4.86 & $5.6^{* * *}$ \\
\hline Political Interest & 0.18 & 15.55 & 6.64 & 21.63 & 7.16 & $4.87^{* * *}$ \\
\hline Materialistic Values & 0.18 & 24.83 & 6.68 & 19.05 & 7.37 & $4.57^{* * *}$ \\
\hline Religious Values & 0.17 & 20.18 & 12.25 & 10.63 & 9.01 & $4.45^{* * *}$ \\
\hline GBJW & 0.17 & 20.71 & 6.77 & 15.45 & 5.03 & $4.43^{* * *}$ \\
\hline Democracy Legitimacy & 0.16 & 18.05 & 4.23 & 21.13 & 2.77 & $4.23^{* * *}$ \\
\hline SDO - Group Dominance & 0.15 & 11.71 & 3.98 & 8.82 & 3.10 & $4.13^{* * *}$ \\
\hline Anomie Perception & 0.15 & 30.72 & 6.45 & 25.82 & 6.66 & $4.08^{* * *}$ \\
\hline Social Trust & 0.09 & 3.53 & 1.63 & 4.45 & 1.64 & $3.05^{* *}$ \\
\hline Political Trust & 0.07 & 14.46 & 4.30 & 12.45 & 4.46 & $2.51^{*}$ \\
\hline Political Tolerance & 0.07 & 26.09 & 9.29 & 30.34 & 8.53 & $2.52^{*}$ \\
\hline Age & 0.06 & 37.08 & 14.24 & 31.39 & 11.62 & $2.25^{*}$ \\
\hline SDO - Opposition to Equality & 0.05 & 8.73 & 3.38 & 7.53 & 2.73 & $2.01^{*}$ \\
\hline Educational Level & 0.04 & 5.11 & 1.20 & 5.50 & 0.95 & 1.83 \\
\hline Political Knowledge & 0.03 & 6.88 & 3.7 & 7.84 & 3.54 & 1.42 \\
\hline Hedonist Values & 0.03 & 25.47 & 7.81 & 27.29 & 5.57 & 1.33 \\
\hline Postmaterialist Values & 0.02 & 76.9 & 9.83 & 74.66 & 9.38 & 1.25 \\
\hline SES & 0.02 & 3.39 & 1.02 & 3.61 & 1.10 & 1.10 \\
\hline $\begin{array}{l}\text { Argentinean Political System } \\
\text { Justification }\end{array}$ & 0.01 & 17.83 & 4.96 & 18.55 & 5.34 & 0.77 \\
\hline
\end{tabular}

aCramer's V Association Coefficient between vote and cluster membership.

The presented results evidenced differences in most of the analyzed dimensions. As we stated, respondents on cluster 1 are mostly Mauricio Macri's voters, identify themselves more with the right, show higher levels of authoritarianism (RWA), conservation values (materialism, religious), conservative ideological orientations (SDO, GBJW) and are politically more cynical and less interested. On the contrary, none of the participants in cluster 2 voted for Mauricio Macri, being more progressive in all the ideological and normative variables. It is relevant to note that differences in democracy legitimacy between groups are not very large, especially regarding specific support (not statistically significant). In this case, too, sociopolitical context evaluation variables showed little relevance. However, cluster 2 embodies a relatively more positive perception of the sociopolitical scenario: people in this cluster tend to be less cynical, perceive less anomie and show more political interest and social trust. Still, despite being more tolerant, they tend to show less political trust.
Finally, people in cluster 2 share most of its political culture characteristics with people that do not justify a coup d'état at all, especially when it comes to ideological orientations. However, we identified some differences mainly regarding their socio-demographic characteristics: they are younger $(t=2.84 ; p \leq 0.01)$, relatively less educated $(t=2.06 ; p \leq 0.05)$ and have a lower $\operatorname{SES}(t=2.09 ; p \leq 0.01)$. Also, they assign less relevance to postmaterialist values $(t=2.54 ; p \leq$ $0.05)$, and more to hedonist values $(t=2.20 ; p \leq$ $0.05)$. They have also shown differences in their electoral preferences: as we mentioned, none of the people on cluster 2 voted for Mauricio Macri, but $42 \%$ do not justify a coup d'état did $(\mathrm{V}=0.36 ; p \leq 0.001)$. It appears that other dimensions being equal, voting for the losing candidate increases the probabilities of justifying a coup d'état.

\section{Discussion}

This article provided an exploratory approach to a problem of great relevance in Latin America, where levels of democracy support decline and authoritarian political expressions proliferate. Given that literature has largely documented that citizens' attitudes and behaviors are relevant to the development and sustainability of democracies, we decided to explore the motivations of people who are willing to justify a coup d'état as a response to economic, social, and political problems framed on a relatively consolidated democracy.

First, we found that people who would justify a coup d'état significantly differ from those who would not do so in all analyzed political culture dimensions. This suggests that political culture is more than an ephemeral superstructure and that adherence to democracy contains more than an expression of social desirability: it has strong social and cultural correlates (Etzioni, 2011). Thus, people who were not willing to justify a coup d'état under any circumstances evidenced - to a greater extent than those who were - many of the characteristics that literature ascribes to a civic culture compatible 
with democracy (e.g., political tolerance, support for postmaterialist values, less authoritarianism) (Welzel \& Inglehart, 2010).

In addition, through a Discriminant Analysis, we were able to identify which of those political culture dimensions were particularly relevant to differentiate between people who would justify a coup d'état and who would not. Normative and system justification motivations were most relevant to differentiate between the two groups, compared to the role of short-term evaluations and those regarding political system performance. Also, the fact that RWA was the main classification variable, while SDO did not have a significant role, is consistent with the dual-process model of ideology: favorable attitudes towards an authoritarian response (coup d'état) to threats to the social order could be expressions of social conservatism (Jugert \& Duckitt, 2009). This is consistent with previous evidence that documents negative relations between RWA and democracy support (Rottenbacher \& Schmitz, 2012). In the same vein, other variables of the conservative conglomerate were also core predictors in the discriminant function. They did so in the same direction: a greater BJW and a rightist ideological position predicted the possibility of justifying a coup d'état, which is also coherent with the cited evidence. To a lesser extent, adscription to postmaterialist values predicted the rejection of a state coup, which is expectable since these values refer more directly to the core of democratic ideal (e.g., freedom, equality, justice) (Inglehart, 2007).

As we pointed out, although we found differences at the univariate level, none of the dimensions regarding the perception of the sociopolitical context were significant predictors in the discriminant model. To some extent, basic commitment to democratic values may override the impact of dissatisfaction with a government or with the sociopolitical situation. The role of political trust, for example, provides evidence in this direction: political trust - a measure relative to institutional performance- was not included in the discriminant function. Also, despite showing differences between groups at the univariate level (t-test), it did so in the opposite direction than theoretically expected: people who would justify a coup d'etat relied more and not less on the state branches. Consistent with some previous evidence, it is possible that trust results to some extent from ideological congruence with the government in office (e.g., Alonso, 2018; Mayne \& Hakhberdian, 2017). Thus, assessments of the honesty and performance of state branches could refer more to ideologically biased orientations than objective judgments about system performance.

Consequently, framed in a center-right government, it is possible that political confidence assessments converge with greater ideological conservatism. Again, most basic and stable orientations seem to explain attitudes towards the political system better. Altogether, this suggests that the erosion of political trust does not necessarily result in an erosion of democracy support, instead of being a symptom of a more critical citizenry with greater democratic pretensions (Hooghe et al., 2017).

Finally, two socio-demographic variables contributed to discrimination between groups: SES and age. Although we expected they were less relevant compared to more specific political orientations, data is coherent with prior regional empirical evidence (Cohen et al., 2017). Most of the literature recognizes that greater SES - mainly in terms of greater access to education - is related to more favorable attitudes towards democracy. On its part, the role of age here is more intriguing. Some literature postulates a cohort effect on the transformations associated with democratic consolidation: younger, more educated, and socialized in democratic generations, would more strongly endorse postmaterialist values and thus have a greater commitment to democracy (Inglehart, 2000). However, our results contradict this hypothesis; younger people were more likely to justify a coup d'état, which matches previous local and regional evidence (Alonso et al., 2018; Cohen et al., 2017). It is possible that having been socialized in democracy may imply a lower capacity of young generations to recognize the extent of the negative impacts of authoritarian regimes on citizenship and thus 
show less rejection to authoritarian interruptions of democracy. On the contrary, older generations have experienced dictatorial regimes and can better recognize the implications of a coup d'état.

Altogether, the evidence points to social values and political ideology as the core of the basic commitment to democracy. However, our exploration of the characteristics of the justify group revealed that underlying motivations do not always come from conservative, status defensive positions. More specifically, a small group of people ideologically progressive and with a strong adherence to democracy were willing to justify the interruption of that democratic order in the face of problems (mainly economic ones) that current democracies experience. It is interesting to note that this group included the youngest and relatively less educated people in the sample, who also voted for the losing candidate (belonging to a center-left party).

It is difficult to understand how this group perceives a coup d'état and what motivations underlie its justification. As we stated, we found no underlying conservative motivations for defending the status quo in this group. Indeed, they did not show differences in respect of the does not justify group in any of the core variables such as the RWA, GBJW, and ideological conservatism, SDO, materialism, and religious values. The main significant differences between these two groups were socio-demographic, ideological congruence with the government in office, and, to a lesser extent, a greater ascription to individualist values (hedonism) rather than collectivist ones (postmaterialist). A plausible hypothesis draws from political alienation analysis: literature suggests that it is possible that lower-status groups feel politically more alienated, which, in turn, could result in greater dissatisfaction and unrest regarding the political system. Something similar could happen with having voted for the losing party since people may not feel represented by the government (Mayne \& Hakhberdian, 2017). In any case, it is relevant to inquire why in this small group this dissatisfaction with the socio-political scenario could result in a greater deposition to justify a coup d'état. At the same time, as we noted, the dimensions regarding the situation assessment did not have any significance in the general sample. This is a question that should be subjected to further analysis.

In the same vein, it would be relevant to deepen our understanding of state coups' perceptions, to identify if it is always perceived as a return to an authoritarian political order. It is possible that for people in cluster 2 who were ideologically progressive- the notion of coup d'état could also refer to interruptions of democracy because of popular social movements (e.g., similar to the exit of President De la Rúa in 2001). This hypothesis also requires further testing. Additionally, it is relevant to investigate the behavioral correlates of these non-democratic attitudes and their implications for democracy stability. In this regard, some literature suggests that people committed to basic democratic values but deeply critical of institutional functioning may entail a reformist force within democracies (Dahlberg et al., 2015). However, our preliminary evidence does not support this hypothesis, as critical citizens were not more politically sophisticated or involved than those who would not accept a coup.

Finally, it is necessary to acknowledge some methodological limitations of this study. Since ours is an exploratory and descriptive analysis, we require complementary studies to test the resulting hypothesis. Additionally, since we took a non-probabilistic sample, generalization to the population must consider these constraints.

\section{Conclusions}

Understanding the bond between the public and the political system and the motivations to defend or not democracy is relevant to find ways to strengthen those ties and improve the quality of democratic processes. This article provided an exploratory contribution, analyzing underlying motivations for the willingness to justify an eventual coup d'état. We found that normative and ideological dimensions of political culture were significant to distinguish between people who would oppose a coup d'état and people 
who would not. Also, evidence suggested that the dissatisfaction of the majorities regarding authorities and political system performance may be mostly channeled through democratic means, as long as people sustain their commitment to basic democratic values. However, we also identified a small group that, would justify a state coup in certain situations, even bearing the characteristics attributed to more democratic citizens. We provided some hypotheses about these motivations, which need further testing, and emphasized the relevance of better understanding people's representations about a coup d'état and the attitudinal and behavioral correlations of political alienation.

\section{References}

Alonso, D. (2018). Análisis multidimensional de legitimidad política [Doctoral Dissertation, Universidad Nacional de Córdoba]. Repositorio Institucional CONICET Digital. https://ri.conicet.gov.ar/handle/113 36/79097

Alonso, D., \& Brussino, S. (2018). Cultura política en un escenario electoral de polarización en Argentina. Revista de Investigación Psicológica, 19, 39-59. http://w ww.scielo.org.bo/pdf/rip/n19/n19_a05.pdf

Alonso, D., Brussino, S., \& Civalero, L. (2018). Demócratas insatisfechos: un estudio sobre actitudes hacia la democracia en Córdoba (Argentina). Polis, 14(1), 107-133. https://doi.org/10.24275/uam/izt/ dcsh/polis/2018v14n1/alonso

Altemeyer, B. (1996). The authoritarian specter. Harvard University Press.

Barros, T. S., Torres, A. R. R., \& Pereira, C. (2009). Autoritarismo e adesão a sistemas de valores psicossociais. PsicoUSF, 14(1), 47-57. https://doi.org/10.1590/s1413-8271 2009000100006

Benbenaste, N., Etchezahar, E., \& Del Río, M. (2008). Psicología de la anomia. Anuario de Investigaciones, 15, 187-193. https://doi.org/ $10.18774 / 448 x \cdot 2008.5 .212$
Brussino, S., Alonso, D., \& Imhoff, D. (2015). Dimensiones culturales, afectivas y cognitivas del comportamiento de voto al kirchnerismo. Revista Psicologia $\mathfrak{E}$ Sociedade, 27(2), 351-361. https://doi.org/1 0.1590/1807-03102015v27n2p351

Brussino, S., Imhoff, D., Rabbia, H. H., \& Paz García, A. P. (2013). Ideología política en torno a issues y valores sociales: un estudio correlacional en ciudadanos de Córdoba/Argentina. América Latina Hoy, 65, 161-182 https://doi.org/10.14201/alh20 1365161182

Brussino, S., Rabbia, H. H., \& Sorribas, P. (2009). Perfiles sociocognitivos de la participación política de los jóvenes. Interamerican Journal of Psychology, 43(2), 279-287. https://www. redalyc.org/pdf/284/28412891009.pdf

Brussino, S., Sorribas, P., \& Medrano, L. (2008). Características psicométricas de la medición del conocimiento político. Revista Iberoamericana de Diagnóstico y Evaluación Psicológica, 25(1), 179-192. https://www.re dalyc.org/pdf/4596/459645445010.pdf

Caprara, G. V., Vecchione, M., Schwartz, S. H., Schoen, H., Bain, P., Silvester, J., Cieciuch, J., Pavlopoulos, V., Bianchi, C., Kirmanoglu, H., Baslevent, C., Mamali, C., Manzi, J., Katayama, M., Posnova, T., Tabernero, C., Torres, C., Verkasalo, M., Lönnqvist, J.-E., Vondráková, E. \& Caprara M. G. (2017). Basic values, ideological self-placement, and voting: A cross-cultural study. CrossCultural Research, 51 (4), 388-411. https://d oi.org/10.1177/1069397117712194

Cohen, M. J., Lupu, N., \& Zechmeister, E. J. (2017). The Political Culture of Democracy in the Americas, 2016/17. A comparative study of democracy and governance, Americas, 2016/17. https://www.vanderbilt.edu/lapop /ab2016/AB2016-17_Comparative_Report _English_V2_FINAL__090117_W.'pdf

Corporación Latinobarómetro (2016). Informe 2016. http://www.latinobarometro.org/latC ontents.jsp

Corporación Latinobarómetro (2018). Informe 2018. http://www.latinobarometro.org/lat.j $\mathrm{sp}$ 
Crawford, J. T., Brandt, M. J., Inbar, Y., Chambers, J. R., \& Motyl, M. (2017). Social and economic ideologies differentially predict prejudice across the political spectrum, but social issues are most divisive. Journal of Personality and Social Psychology, 112(3), 383-412. https://doi.org/10.1037/pspa0000 074

Dahlberg, S., Linde, J., \& Holmberg, S. (2015). Democratic discontent in old and new democracies: Assessing the importance of democratic input and governmental output.Political Studies, 63(1), 18-37. https: //doi.org/10.1111/1467-9248.12170

Dimdins, G., Sandgren, M., \& Montgomery, H. (2016). Psychological variables underlying political orientations in an old and a new democracy: A comparative study between Sweden and Latvia. Scandinavian Journal of Psychology, 57(5), 437-445. https://doi.org/ 10.1111/sjop.12314

Etchezahar, E., Cervone, N., Biglieri, J., \& Quattrocchi, P. (2011). Adaptación y validación de la versión reducida de la escala de autoritarismo de derechas (RWA) al contexto argentino. Anuario de Investigaciones, 19(1), 237-242. https://doi. org/10.5354/0719-0581.2010.17098

Etchezahar, E., Prado-Gascó, V., Jaume, L., \& Brussino, S. (2014). Validación argentina de la Escala de Orientación a la Dominancia Social. Revista Latinoamericana de Psicología, 46(1), 35-43. https://doi.org/1 0.1016/s0120-0534(14)70004-4

Etzioni, A. (2011). On communitarian and global sources of legitimacy. The Review of Politics, 73(1), 105-122. https://doi.org/10.1017/s00 34670510000884

Fuks, M., Casalecchi, G. A., \& Araújo, M. M. (2017). Are dissatisfied democrats critical? Reevaluating the concept of the critical citizen. Opinião Pública, 23(2), 316-333. https://doi.org/10.1590/1807-019 12017232316

Gibson, R. K., \& McAllister, I. (2015). New media, elections and the political knowledge gap in Australia. Journal of
Sociology, 51 (2), 337-353. https://doi.org/10 $.1177 / 1440783314532173$

Grigera, A., Pascale, B. G., \& Alsina, R. (2015, August 15). La sociedad frente al espejo. Algunos elementos para pensar la democracia desde el capital social. En el XII Congreso Nacional de Ciencia Política, organizado por la Sociedad Argentina de Análisis Político y la Universidad Nacional de Cuyo, Mendoza.

Hooghe, M., Marien, S., \& Oser, J. (2017). Great expectations: the effect of democratic ideals on political trust in European democracies. Contemporary Politics, 23(2), 214-230. https://doi.org/10.1080/13569775 .2016 .1210875

Índice de Desarrollo Democrático de América Latina [IDD-LAT]. (2016). Índice de Desarrollo Democático de América Latina IDD-LAT 2016. Uruguay: Fundación Konrad Adenauery, Polilat.com. http://iddlat.org/2016/informes/2016/index.html

Inglehart, R. (2000). Globalization and postmodern values. Washington Quarterly, 23(1), 215-228. https://doi.org/10.1162/01 6366000560665

Inglehart, R. (2007). Mapping Global Values. En Y. Esmer \& T. Pettersson (Eds.), Measuring and Mapping Cultures: 25 Years of Comparative Value Surveys (pp. 115-136). Brill.

Jost, J. T. (2019). A quarter century of system justification theory: Questions, answers, criticisms, and societal applications. British Journal of Social Psychology, 58(2), 263-314.

Jost, J. T., Hawkins, C. B., Nosek, B. A., Hennes, E. P., Stern, C., Gosling, S. D., \& Graham, J. (2013). Creencia en un Dios justo: La religión como una forma de justificación del Sistema. Psicología Política, 47, 55-89. https://www.uv.es/garzon/psicol ogia\%20politica/N47-4.pdf

Jugert, P., \& Duckitt, J. (2009). A motivational model of authoritarianism: Integrating personal and situational determinants. Political Psychology, 30(5), 693-719. https:// doi.org/10.1111/j.1467-9221.2009.00722.x 
Kandler, C., Bell, E., \& Riemann, R. (2016). The structure and sources of right-wing authoritarianism and social dominance orientation. European Journal of Personality, $30(4), 406-420$.

Katz, G., \& Levin, I. (2017). Varieties of political support in emerging democracies: A crossnational analysis. Social Science Research, 70, 55-70. https://doi.org/10.1016/j.ssresear ch.2017.11.002

Latin American Public Opinion Project [LAPOP]. (2014). AmericasBarometer 2014. Estados Unidos: Vanderbilt University. http s://www.vanderbilt.edu/lapop/ab2014.php

Laca Arocena, F. A., Mejía Ceballos, J. C., \& Yañez Velasco, C. (2010). Identidad mexicana e interés político: Predictores de bienestar social y anomia. Acta Universitaria, 20(2), 40-49. https://doi.org/1 $0.15174 /$ au.2010.79

L,evina, J., Mārtinsone, K., \& Klince, K. (2016, May 27). Relations between anomia and values of the inhabitants of the Baltic States [Presentation]. Proceedings of the International Scientific Conference. https:/ /doi.org/10.17770/sie2016vol1.1522

Levine, D. H., \& Molina, J. E. (2007). La calidad de la democracia en América Latina: una visión comparada. América Latina Hoy, 45, 17-46. https://www.redalyc.org/pdf/308/30 804502.pdf

Lipkus, I. (1991). The construction and preliminary validation of a global belief in a just world scale and the exploratory analysis of the multidimensional belief in a just world scale. Personality and Individual Differences, 12(11), 1171-1178. https://doi. org/10.1016/0191-8869(91)90081-1

Magalhães, P. C. (2016). Economic evaluations, procedural fairness, and satisfaction with democracy. Political Research Quarterly, 69(3), 522-534. https://doi.org/10.1177/10 65912916652238

Marenco dos Santos, A. (2006). Instituciones o cultura: ide qué materia prima está hecha la legitimidad de las nuevas democracias? Revista Desarrollo y Sociedad, 58, 261-289. h ttps://doi.org/10.13043/dys.58.8
Mayne, Q., \& Hakhverdian, A. (2017). Ideological congruence and citizen satisfaction: Evidence from 25 advanced democracies. Comparative Political Studies, 50(6), 822-849. https://doi.org/10.1177/00 10414016639708

Mishler, W., \& Rose, R. (2001). What are the origins of political trust? Testing institutional and cultural theories in postcommunist societies. Comparative Political Studies, 34(1), 30-62. https://doi.org/10.117 $7 / 0010414001034001002$

Muraro, O. (2012). El NSE en la encuesta anual de hogares urbanos (INDEC). Sociedad Argentina de Investigadores de Marketing y Opinión. http://www.saimo.org.ar/archivos /observatorio-social/NSE-en-la-EAHU.pdf

Murillo, M. V., \& Visconti, G. (2017). Economic performance and incumbents' support in Latin America. Electoral Studies, 45, 180-190. https://doi.org/10.1016/j.electstu d.2016.10.007

Muñiz, C., Téllez, N. M., \& Saldierna, A. R. (2017). La sofisticación política como mediadora en la relación entre el consumo de medios y la participación ciudadana: Evidencia desde el modelo OSROR. Comunicación y Sociedad, 30(3), 255-274. h ttps://doi.org/10.15581/003.30.3.255-274

Oscarsson, H., \& Rapeli, L. (2018). Citizens and Political Sophistication. In Oxford Research Encyclopedia of Politics. https://doi.org/10.10 93/acrefore/9780190228637.013.220

Pattyn, S., Van Hiel, A., Dhont, K., \& Onraet, E. (2012). Stripping the political cynic: A psychological exploration of the concept of political cynicism. European Journal of Personality, 26(6), 566-579. https://doi.org/ 10.1002/per.858

Pereira, C., Camino, L., \& Bastos da Costa, J. (2004). Análise fatorial confirmatória do Questionário de Valores PsicossociaisQVP24. Estudos de psicologia, 9(3), 505-512. https://doi.org/10.1590/s1413-29 $4 \times 2004000300013$

Pereira, C., Camino, L., \& Bastos da Costa, J. (2005). Um estudo sobre a integração dos níveis de análise dos sistemas de 
valores. Psicologia: reflexão e crítica, 18(1), 16-25. https://doi.org/10.1590/s0102-7972 2005000100004

Pereira, C., Lima, M. E., \& Camino, L. (2001). Sistemas de valores e atitudes democráticas de estudantes universitários de João Pessoa. Psicologia: Reflexão e Crítica, 14(1), 177-190. https://doi.org/10.1590/s01 02-79722001000100015

Rodríguez García, J. M. (2006). Análisis comparativo de confiabilidad y validez de dos escalas de anomia. Interamerican Journal of Psychology, 40(2), 193-204. https://www. redalyc.org/pdf/284/28440206.pdf

Rottenbacher, J. M., \& Schmitz, M. (2012). Conservadurismo político y tolerancia hacia comportamientos transgresores. Revista Psicología Politica de la Universidad de Valencia, 44, 31-56. https://psycnet.apa.org/ record/2012-12722-002

Rutto, F., Russo, S., \& Mosso, C. (2014). Development and Validation of a Democratic System Justification Scale. Social Indicators Research, 118, 645-655. htt ps://doi.org/10.1007/s11205-013-0444-2

Santiago, M. A., Hernández, J., \& Martínez, A. (2020). Capital social, en la construcción de la democracia. Orbis: Revista de Ciencias Humanas, 16(46), 20-30. https://dialnet.un irioja.es/servlet/articulo? codigo $=7610331$

Segovia, C., Haye, A., González, R., Manzi, J., \& Carvacho, H. (2008). Confianza en instituciones políticas en Chile: un modelo de los componentes centrales de juicios de confianza. Revista de Ciencia Politica (Santiago), 28(2), 39-60. https://doi.org/10. 4067/s0718-090x2008000200002

Solano Silva, D. (2018). Conservadurismo y orientación política, isu relación es similar en Latinoamérica y Occidente? Psicoperspectivas. Individuo y Sociedad, 17(1), 1-11. https://doi.org/10.5027/psicoperspect ivas-vol17-issue1-fulltext-1098

Svampa, M. (2019). Posprogresismos, polarización y democracia en Argentina y Brasil. Nueva Sociedad, 282, 121-134. https://nuso.org/articulo/posprogr esismos-polarizacion-y-democracia-en-arge ntina-y-brasil/

Teymoori, A., Bastian, B., \& Jetten, J. (2017). Towards a psychological analysis of anomie. Political Psychology, 38(6), 1009-1023. https ://doi.org/10.1111/pops.12377

Vargas-Cullell, J., Rosero-Bixby, L., \& Seligson, M. A. (2005). La cultura política de la democracia en Costa Rica, 2004: un estudio del Proyecto de Opinión Pública en América Latina (OPAL). Centro Centroamericano de Población. http://hdl.handle.net/10669/ 75348

Welzel, C., \& Inglehart, R. (2010). Chapter 17: Political Culture. In D. Caramani (Ed.), Comparative Politics (pp. 284-301). Oxford University Press.

Zovatto, D. (2018). El estado de las democracias en América Latina a casi cuatro décadas del inicio de la Tercera Ola Democrática. Revista de Derecho Electoral, 25, 1-24. https://www.tse.go.cr/revista/art/2 5/zovatto_garetto.pdf

\section{Notes}

* $\quad$ Research article. This research was carried in a CONICET project. 